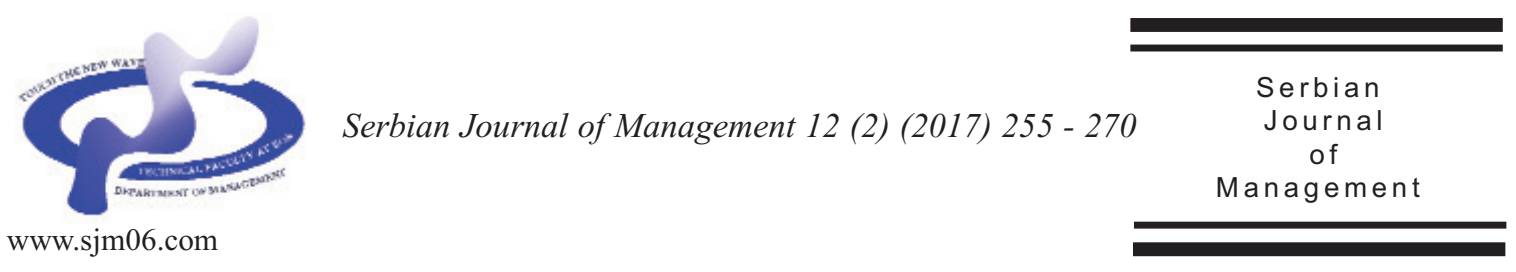

\title{
MEASURING OF HUMAN DEVELOPMENT THROUGH THE OUTPUT-ORIENTED SUPER EFFICIENCY VRS DEA MODEL WITHOUT INPUTS
}

\author{
Miraç Eren $^{a *}$, Murat Eren ${ }^{b}$, Selim Başar ${ }^{b}$ \\ ${ }^{a}$ Ondokuz Mayls University, Department of Economics, Samsun, Turkey

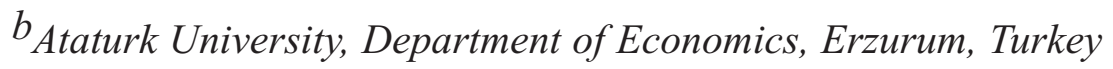

(Received 20 June 2017; accepted 02 August 2017)

\begin{abstract}
The Human Development Index (abbv. HDI) being a popular measure of human well-being has become a measure of human development. However, the HDI has received the major criticisms relating the data structure and the particularly equal weighting scheme. In this study, to eliminate mentioned shortcomings, the measurement of human development was again revisited in the light of data envelopment analysis (DEA). All of the variables used in HDI account were taken as output variables to sort out the relative performance of the countries. In the absence of input variables, and a case in which there are only output variables was reorganized by the formulation of superefficiency model developed by Andersen and Petersen (1993). The formulation obtained was applied to the Radial based DEA model without inputs, which it is considered as the output of all of the relevant variables, and developed by Lovell and Pastor (1999).
\end{abstract}

Keywords: Human Development Index; Data Envelopment Analysis; Efficiency

\section{INTRODUCTION}

\subsection{The Definition and History of Human Development Index (HDI)}

Economists have addressed regarding per capita income to questions such as how has world wellbeing evolved over the long run?
How can regions be compared to each other? Have their differences widened (Prados de la Escosura, 2015)? Human wellbeing is widely viewed, however, as a multidimensional phenomenon, in which income is only one facet. For this reason, new approaches appeared after 1970's which aim to define development expressing

\footnotetext{
* Corresponding author: mirac.eren@omu.edu.tr
}

DOI: $10.5937 /$ sjm12-11184 
human prosperity with its social, cultural, environmental and spatial dimensions (DPT, 2007). As a result of, non-income dimensions of well-being such as infant mortality, life expectancy at birth, height literacy, etc. have been used individually or combined into a composite index (physical quality of life, basic needs, and more recently human development) to provide welfare measures that go beyond gross domestic product (GDP). This composite index obtained was called as Human Development Index (HDI).

HDI being a popular measure of human well-being is annually reported by the United Nations Development Program (UNDP). In this report, life expectancy, education, and GDP indexes are created based on factors such as a long and healthy life, social and political independence, human rights. As a result of, HDI index information such as the fact whether the relevant country is a developed, developing or underdeveloped country, and also to what extent its economy affects the life quality is presented.

HDI was initially developed in 1990 by Mahbubul Haq, a Pakistani economist and has been submitted in annual development report by United Nations Development program since 1993 (Prados de la Escosura, 2015). The three core dimensions of the HDI were life expectancy (LE), schooling (S) and income (Y). According to the 20th human development report published in 2010, there have been some changes in the HDI measurement. According to last calculation, life expectancy is the only core dimension that is unchanged in the 2010 HDI. Gross national income (GNI) has replaced GDP calculated according to purchasing power parity (PPP). Literacy and the gross enrollment rate (as used in the former HDI) have been replaced by mean years of schooling (MS) and the expected years of schooling (ES), given by the years of schooling that a child can expect to receive given current enrolment rates (Ravallion, 2012).

As in the past, the three core dimensions of the HDI are first put on a standard $(0,1)$ scale. The rescaled indicators are:

$$
\begin{aligned}
& I_{x}=\frac{x-x^{\min }}{x^{\max }-x^{\min }}, \quad(x=L E, S) \\
& I_{Y}=\frac{\ln Y-\ln Y^{\min }}{\ln Y^{\max }-\ln Y^{\min }}
\end{aligned}
$$

It is assumed that $x_{\min } \leq x_{i} \leq x_{\max }(\mathrm{x}=\mathrm{LE}$, $\mathrm{S}, \mathrm{Y}$ ) for all $\mathrm{i}$. Where $I_{s}$ is itself a composite index of Mean Years of Schooling (MS) and Expected Years of Schooling (ES). From here, $I_{s}$ index of the new HDI has calculated as:

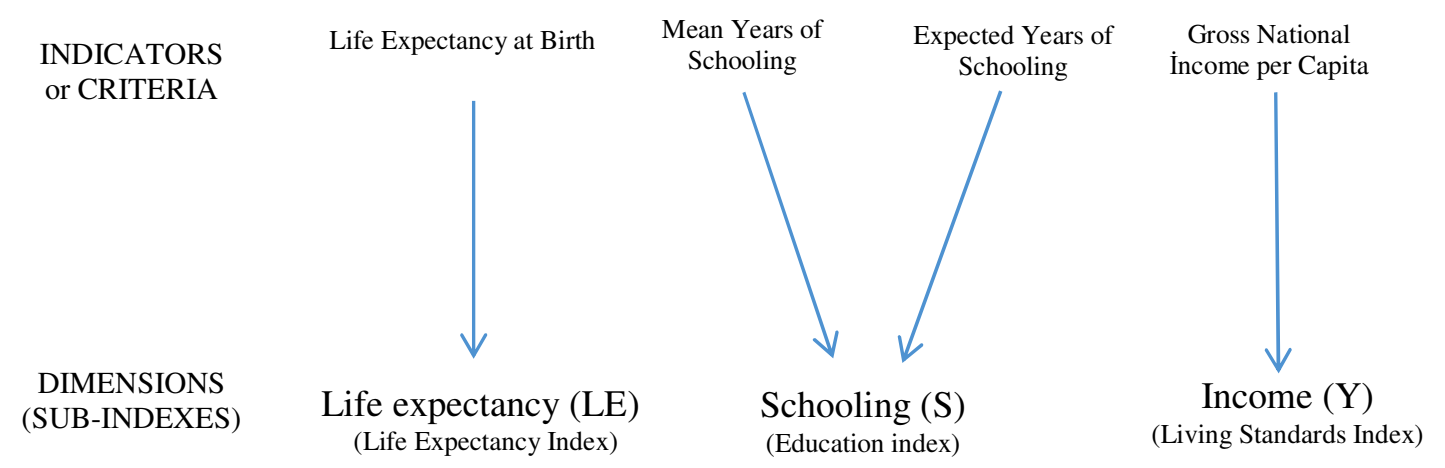

Figure 1. The HDI dimensions and indicators - Source: UNDP, Human Development Report, 2010. 


$$
I_{S}=\left(M S / M S^{\max }\right)^{0.5}\left(E S / E S^{\max }\right)^{0.5}
$$

For the 2010 HDI, life expectancy is bounded below by 20 years, and above by 83.2 years (Japan's life expectancy). GNI per capita is bounded below by $\$ 163$ (the lowest value, for Zimbabwe in 2008) and above by $\$ 108,211$ (for the United Arab Emirates in 1980). The new education variables are both taken to have lower bounds of zero with MS bounded above by 13.2 years (the US in 2000), and ES bounded above by 20.6 years (Australia, 2002) (Ravallion, 2012).

An important change is about how the three scaled indicators are aggregated. While the former HDI used arithmetic means (that is $\left.H D I_{\text {old }}=\left(I_{L E}+I_{S}+I_{Y}\right) / 3\right)$ of variables, 2010 HDI used their geometric means:

$$
H D I_{\text {new }}=I_{L E}^{1 / 3} \cdot I_{S}^{1 / 3} \cdot I_{Y}^{1 / 3}
$$

As a result, countries are classified as very high human development, high human development, medium human development, and low human development.

\subsection{Literature Review}

Among the indexes aiming to measure human development, HDI had been one of the most prevalently used indicators for prosperity comparisons in its 20 years of history due to its transparency and simplicity as well as multi-dimensional prosperity measurement (Harttgen \& Klasen, 2012). However, HDI received serious criticisms varying from its creation and composition to its expansion and containing more dimensions.

Critiques regarding HDI can be investigated in three broad categories. Accordingly, the first group of critiques relates to dimensions and indicators of the HDI. Ogwang (1994) found that life expectancy would be the best choice to represent the three components of the HDI, and thus suggested one variable selection strategy. Accordingly, it was determined that a simplified HDI could be obtained, without loss of too much information and at a lower cost, by subtracting the life expectancy deprivation index from unity. Engineer et al. (2008) argued that it is better to drop the income component from the HDI because it does not play its expected role of accessing a decent standard of living.

Bhanojirao (1991) suggested the inclusion of additional dimensions such as political, economic and social freedom, opportunities for being creative and productive, personal self-respect, and guaranteed human rights. Ranis et al. (2005) stressed the need of neglecting some relevant dimensions and identified new categories encompassing all the major dimensions of human development. Sanusi (2008) implied that housing facilities and housing conditions increased the scope of human development, and thereby tried to widen the scope of issues covered by the HDI.

Dias et al. (2006), Moran et al. (2008), Morse (2003) and Neumayer (2001) were concerned about consideration of natural resources conservation, environment, and national energy uses concepts in development measuring.

The second group of critiques is based that the HDI do not take into account inequality within countries. According to this opinion, the HDI looks at the average achievements and does not reflect the distribution of human development within a country. Some adjustments to variables such as gender, ethnic and income groups have been suggested To eliminate the concept of 
inequality.

The UNDP offered the Gender-Related Development Index (GDI) in the direction of this second group of critiques. The GDI adjusts the HDI by eliminating gender inequalities in life expectancy, education, and income dimensions by measuring each indicator separately for men and women, and then calculating the harmonic mean of them (UNDP, 1995).

About income inequality, Hicks (1997) suggested an Inequality-Adjusted Human Development Index (IHDI) together with the HDI by proposing to discount each dimensional index by one minus of the Gini coefficient before the mean of the indexes of life, education and income are taken. Afterward, Sagar and Najam (1998) pointed out that the use of the GDP per capita component as a proxy for average income would not allow for major differences in income distribution within a country.

Harttgen and Klasen (2012) proposed a method to calculate a proxy HDI at the household level to allow the analysis of the inequality in human development among population subgroups according to socioeconomic characteristics.

The third group of critiques is related to HDI analytical framework and methodology. Firstly regarding methodological framework, an arbitrary equally weighting of the education, life and income indexes of the HDI was criticized (Kelley, 1991; Ravallion, 1997; Srinivasan, 1994). Afterward, resulting in a modified version of HDI index, it was suggested some modifications in two categories of technical issues ranging from those related to the components of the index to those relevant to the structure of the index (Noorbakhsh, 1998).

Wolff et al. (2011) calculated the likelihood of each country's deviation from the original published HDI rank. Also, they mentioned from the data errors such as the measurement error due to data updating, the data noise due to formula revision and the misclassification due to inconsistent thresholds of classifying a country's development status.

There are also some the different methodological approaches which are used to calculate the rank of countries. The framework providing a fuzzy representation of the HDI and its three components (Baliamoune-Lutz \& McGillivray, 2006), the Multiple Criteria Decision Making (MCDM) technique (Safari \& Ebrahimi, 2014) and DEA-like linear programming model that are developed to assess the relative performance of the countries in terms of human development (Despotis, 2005) are some of these ranking methodologies.

It is more important to determine an appropriate measurement method rather than a selection of the indicator variables and consideration inequality within countries to measure human development. Since, as it appears from the literature, made with an arbitrary equally weighting of the variables used in the HDI calculation and being a simple index based on a geometric mean is a situation that has been criticized. If this fundamental problem for the measurement of human development is exceeded, then it can be re-ranking of countries by considering the different indicator variables. However, the various methodologies as MCDM which are used to calculate the rank of countries may reveal different rankings. So, in this study, the Data Envelopment Analysis (DEA) which is a linear programming model was used to rank countries according to their level of development.

Because of the multidimensional nature of human development, it is hard to measure 
and analyze HDI. Since DEA analysis provides a significant contribution to the better understanding and study of this process, it has been commonly used in the literature. A literature review paper towards the utilization of the DEA conducted for the measurement of human development is made by Mariano et al. (2015).

\section{METHODOLOGY}

\subsection{Data Envelopment Method}

The idea of measuring and analyzing human development is a difficult situation, due to its multi-dimensional nature. Therefore, DEA can significantly contribute to this process by making it possible to study better and understand.

DEA is a methodology that allows relative evaluation of the performance of a set of the comparable entities called Decision Making Units (DMUs) which convert multiple inputs into multiple outputs (Cooper et al., 2011). The DEA approach that determines the set of weights by optimizing the efficiencies of decision units for a mathematical model combining in a unity score of multiple input and output without requiring a common unit of measure is a mathematical procedure based on linear programming (Cooper et al., 2007). Moreover, it identifies an efficient frontier where all DMUs have a unity score. If there are DMUs which are on this efficient frontier, then, these DMUs are referred to as efficient decision units (Ebadi, 2012). Initially, CRS Constant Returns to Scale (CRS) model was introduced in 1978 by Charnes, Cooper and Rhodes. Variable Returns to Scale (VRS) model was introduced by Banker, Charnes and Cooper in 1984. Following years, differentiations occurred together with the models such as the Additive Model, A Slacks-Based Measure of Efficiency (SBM).

Many DEA models can be established according to application areas and assumptions. These models can be separated into two main groups as input or output oriented. The one's input oriented examine to what extent they should decrease the inputs of decision units which are not effective at any output level. Similarly, effectiveness measures aiming at output focus on to what extent they can increase their outputs so as to efficient the inefficient decision units for any input composition. Accordingly, it is stated that "Input oriented models decrease input usage proportionally at constant output level so as to measure technical ineffectiveness." If the models can not be configured as input or output oriented, integrated models can be used. The two scale values are observed to give same value at CRS, and it is little different in comparison with VRS. In the majority of studies in literature, as input amount appears to be primary decision variable, input-oriented models were frequently selected. However, there can be some cases in which source quantity is kept constant, and output quantity is increased as much as possible. In the last case, output focused model is more suitable (Coelli \& Perelman, 2000). Accordingly, the mathematical expressions of CRS and VRS models are presented in Table 1.

According to Table 1, $\mathrm{X}$ is the matrix providing the inputs for all decision units in $\mathrm{n} \times \mathrm{m}$ dimension and $\mathrm{Y}$ is the matrix providing the outputs of all decision units in $\mathrm{n} \times \mathrm{s}$ dimension. Accordingly, the vectors with a $m \times 1$ and $s \times 1$ dimension which respectively provide the inputs and outputs of that decision unit are input and output weighted vectors. Again $\theta_{0}$ and $\varnothing_{0}$ which are a scalar 
Table 1. Mathematical Expressions of the Models of the Constant Return to Scale and Variable Return to Scale

\begin{tabular}{|c|c|c|}
\hline & Primal & Dual \\
\hline \multirow{5}{*}{ Input oriented } & $\operatorname{mak} \quad z_{o}=\sum_{r=1}^{s} u_{i} y_{i o}-\left(u_{o}\right)^{*}$ & $\min \theta_{o}$ \\
\hline & Subjects to: & Subjects to: \\
\hline & $\sum_{i=1}^{m} v_{i} x_{i o}=1$ & $\sum_{j=1}^{n} \lambda_{j} x_{i j}-\theta_{o} x_{i o} \leq 0 \quad i=1, \ldots, m$ \\
\hline & $-\sum_{i=1}^{m} v_{i} x_{i j}+\sum_{r=1}^{s} u_{r} y_{r j}-\left(u_{o}\right)^{*} \leq 0$ & $y_{r o}-\sum_{r=1}^{s} \lambda_{j} y_{i j} \leq 0 \quad r=1, \ldots, \mathrm{s}$ \\
\hline & $v_{i} \geq 0 \quad u_{r} \geq 0 \quad u_{o}$ Infinite & $\left(\sum_{j=1}^{n} \lambda_{j}=1\right)^{*}$ \\
\hline \multirow{5}{*}{$\begin{array}{l}\text { Output } \\
\text { oriented }\end{array}$} & $\min z_{o}=\sum_{i=1}^{m} v_{i} x_{i o}-\left(v_{o}\right)^{*}$ & mak $\phi_{o}$ \\
\hline & Subjects to: & Subjects to: \\
\hline & $\sum_{r=1}^{s} u_{r} y_{i j}=1$ & $\sum_{j=1}^{n} \lambda_{j} x_{i j}-x_{i o} \leq 0 \quad i=1, \ldots, m$ \\
\hline & $\sum_{i=1}^{m} v_{i} x_{i j}-\sum_{r=1}^{s} u_{r} y_{r j}-\left(v_{o}\right)^{*} \leq 0$ & $\phi_{o} y_{r o}-\sum_{r=1}^{s} \lambda_{j} y_{i r} \leq 0 \quad r=1, \ldots, \mathrm{s}$ \\
\hline & $v_{i} \geq 0 \quad u_{r} \geq 0 \quad v_{o}$ Infinite & $\left(\sum_{j=1}^{n} \lambda_{j}=1\right)^{n}$ \\
\hline
\end{tabular}

(*) it is added as a constraint for VRS model

units are the effectiveness score of the decision unit. Under these assumed limitations, the model is solved separately for $n$ decision units, and score values of each decision unit are obtained. As primal linear model's number of limitations is higher compared to the dual one, the dual model is preferred regarding ease of operation.

\subsection{DEA Models without Inputs}

Sometimes, for each DMU, there may be a condition which there are only the output variables in the absence of input variables of them. For example, all of the variables (namely, variables such as life expectancy at birth, mean years of schooling, expected years of schooling, gross national income per capita used to create the HDI) used for ranking of the countries efficiency values are output in the DEA analysis in this study. If a composite index (CI) that will be created by using DEA has only the desirable attributes in this way, then the approach utilized will be called as "the benefit of the doubt (BoD)" (Mariano et al., 2015). While the standard DEA models are based on the ratio between desirable (more-the-better) and undesirable (less-the-better) performance measures, BoD models use only the desirable attributes and are exclusively focused on aggregating outputs. In this regard, BoD differs from the 
standard DEA-models (De Witte et al., 2013).

The radial based DEA without inputs models developed by Lovell and Pastor (1999) suggested that efficiency measurements will be performed through output variables for a case in which there are no input variables.

Lovell and Pastor (1999) have proven the below properties for models mentioned above:

I) Without input (or without output) CRS models can not distinguish efficient and inefficient units.

II) Output oriented CRS models with single constant input, and input-oriented CRS models with single constant output collide with related VRS models.

III) Output oriented VRS models with constant input (or input oriented with single constant output) are equivalent to VRS models without input (or without output).

IV) All VRS models without input (or without output) can be summarized with models having single incomplete variable and single incomplete constraint.

In an output focused model, aim function maximizes the output and provide income level. This model seeks to produce maximum output with current input. The situation where source amount is constant and accordingly increasing output amount as much as possible is desired by country governing people, and also it is easier to control. For this reason, it was stated by Lovell and Pastor (1999) that output oriented VRS model is suitable to make an evaluation by taking advantage of radial based DEA models without input. As a matter of fact, this corresponds to output oriented VRS model having single constant input. In fact, according to (II) item, output oriented CRS model having single constant input collides with VRS model. Namely, both of them express the same thing. Accordingly, the mathematical expressions of primal and dual of output focused DEA models without input are presented in Table 2 .

This BoD approach put forwarded by Lovell and Pastor (1999) was firstly used to recalculate HDI by Mahlberg and Obersteiner (2001). Afterward, the advances in the BoD approach were presented by De Witte et al. (2013) and Färe and Karagiannis (2014). However, it is observed that none of these studies consists of eliminating from the linear programming model the restriction that limits to one the efficiency of the unit being analyzed. If the restriction that limits to one the efficiency of the unit being analyzed is eliminated from the linear programming model, then, this construction

Table 2. The output-oriented VRS model without inputs

\begin{tabular}{cll}
\hline & Primal & Dual \\
\hline & min $z_{o}=-v_{o}$ & mak $\phi_{o}$ \\
The output- \\
oriented VRS \\
$\begin{array}{c}\text { Subjects to: } \\
\text { inputs }\end{array}$ & $\sum_{r=1}^{s} u_{r} y_{r o}=1$ & Subjects to: \\
& $\sum_{r=1}^{s} u_{r} y_{r j}+v_{o} \leq 0, \quad$ and $\quad j=1, \ldots, n$ & $\phi_{o} y_{r o}-\sum_{r=1}^{s} \lambda_{j} y_{i r} \leq 0 \quad r=1, \ldots, \mathrm{s}$ \\
& $v_{i} \geq 0 \quad u_{r} \geq 0 \quad v_{o}$ Infinite &
\end{tabular}


is called as super efficiency model. According to this, when $\mathrm{BoD}$ approach is applied on super efficiency model, the sequencing of DMUs will again be provided according to a composite index (CI).

\subsection{A Super Efficiency Model without Inputs for Ranking Units in DEA}

According to the optimal solution of the output-oriented radial DEA model without inputs shown in Table 2. If a DMU achieves the maximum possible value of $100 \%$, it is efficient. Otherwise, it is inefficient, and the ratio values of which are inefficient are above one (Poveda, 2011). However, it may sometimes be necessary to rank the performance of efficient DMUs. For such a situation, super efficiency model has been proposed by (Andersen \& Petersen, 1993).

Super efficiency DEA models also called as AP models can be used in ranking the performance of efficient DMUs. In fact, when a DMU under evaluation is not included in the reference set of the original DEA models, the resulting DEA models are called super-efficiency DEA models. Additionally, the super-efficiency DEA model can be obtained as either situation CRS or VRS (Ebadi, 2012).

For the aim of ranking countries according to the variables used in the HDI calculation, if the formulation of superefficiency model developed by Andersen and Petersen (1993) is applied to the Radial based DEA model without inputs, which it is considered as the output of all of the relevant variables, developed by Lovell and Pastor (1999), it can be achieved the ranking of the countries called as decision-making units. Accordingly, mathematical expressions of primal and dual of output focused super affectivity DEA models without input formed for ranking DMU's are presented in Table 3.

\section{MODEL, RESULTS, AND DISCUSSION}

The aim of this analysis is to compare results of the traditional HDI scale and the output-oriented super-efficiency DEA model without inputs put forward by the research and to propose a new scaling to measure human development. Then, when an output-

Table 3. The output-oriented super efficiency VRS model without inputs

\begin{tabular}{|c|c|c|}
\hline & Primal & Dual \\
\hline & $\min z_{o}=-v_{o}$ & mak $\phi_{o}$ \\
\hline $\begin{array}{c}\text { The } \\
\text { Output- }\end{array}$ & Subjects to: & Subjects to: \\
\hline $\begin{array}{l}\text { Oriented } \\
\text { Super } \\
\text { Efficiency }\end{array}$ & $\sum_{r=1}^{s} u_{r} y_{r o}=1$ & $\phi_{o} y_{r o}-\sum_{\substack{j=1 \\
j \neq o}}^{n} \lambda_{j} y_{r j} \leq 0, \quad r=1, \ldots, s$ \\
\hline $\begin{array}{l}\text { VRS Model } \\
\text { Without }\end{array}$ & $\sum_{r=1}^{s} u_{r} y_{r j}+v_{o} \leq 0, \quad j=1, \ldots, \mathrm{n} \quad$ and $\quad j \neq o$ & $\sum_{i=1}^{n} \lambda_{j}=1$ \\
\hline Inputs & $v_{i} \geq 0 \quad u_{r} \geq 0 \quad v_{o}$ Infinite & $j \neq o$ \\
\hline
\end{tabular}


oriented super-efficiency DEA model without inputs with the output variables (life expectancy at birth- LE, mean years of schooling- MS, expected years of schoolingES, gross national income (GNI) per capitaGNIpc) used in the calculation of HDI index is created in order to evaluate the relative performance of 187 countries being the comparable entities, this model is equivalent to VRS DEA model with four outputs. Let $\varnothing$ be the optimal value of the objective function when the model is solved for country j. So, dual of the proposed model is:

Dual model: $\max \varnothing_{o}$

Subjects to:

$$
\begin{aligned}
& \phi_{o} \cdot L E_{o}-\sum_{\substack{j=1 \\
j \neq o}}^{187} \lambda_{j} \cdot L E_{j} \leq 0 \\
& \phi_{o} \cdot \mathrm{MS}_{o}-\sum_{\substack{j=1 \\
j \neq o}}^{187} \lambda_{j} M S_{j} \leq 0 \\
& \phi_{o} \cdot E S_{o}-\sum_{\substack{j=1 \\
j \neq o}}^{187} \lambda_{j} \cdot E S_{j} \leq 0 \\
& \phi_{o} \cdot G N I p c_{o}-\sum_{\substack{j=1 \\
j \neq o}}^{187} \lambda_{j} \cdot G N I p c_{j} \leq 0 \\
& \sum_{\substack{j=1 \\
j \neq 0}}^{n} \lambda_{j}=1 \\
& \lambda_{j} \geq 0
\end{aligned}
$$

In those above dual mathematical model, it is written a constraint corresponding to each output variable. However, if the primal of the model were constructed, a constraint for each country would be written, which would cause the model to expand too much and extend the solution period. If so, efficiency scores obtained from countries together with the solution of presented optimization model as follows:

When "The Output-Oriented Super Efficiency VRS DEA Model without Inputs" established is solved for each country, the results obtained are given in Table 4-Table 7.

HDI index is calculated according to values of LE, MS, ES and GINI variables. According to the findings, the countries demonstrating a high degree of deviation in suggested DEA efficiency score ranking together with HDI index rating were observed to be originated from the fact that they have too high or too low values regarding values of variables according to HDI calculation used compared with other nearby countries. According to results presented in Table 4- Table 7.

When obtained findings are evaluated, it is understood that the relative value in any of the output variables of the application is subject to a ranking originated from the fact that it is too high or too low compared with the others. The application determines the efficiency score of the country according to the variable demonstrating high degree of deviation from the value average of countries incorporated into the model and forms the effective ranking accordingly. This fact shows that the variables which are the base for calculation while HDI index is calculated, were not used at efficient ratios and that the ranking was not realized with the real values of countries. 
Table 4. Data and optimization results for the countries in a group of Very high human development according to the proposed "Output-Oriented Super Efficiency VRS DEA Model without Inputs"

\begin{tabular}{|c|c|c|c|c|}
\hline New Ranking & HDI Ranking & HDI Group & Countries & Efficiency Scores \\
\hline 1 & 31 & very high & Qatar & 0.7316 \\
\hline 2 & 2 & very high & Australia & 0.9545 \\
\hline 3 & 1 & very high & Norway & 0.9643 \\
\hline 4 & 5 & very high & United States & 0.9901 \\
\hline 5 & 17 & very high & Japan & 0.9923 \\
\hline 6 & 9 & very high & Singapore & 0.9934 \\
\hline 7 & 6 & very high & Germany & 0.9951 \\
\hline 8 & 15 & very high & Hong Kong. China (SAR) & 0.9955 \\
\hline 9 & 3 & very high & Switzerland & 0.9963 \\
\hline 10 & 13 & very high & Iceland & 1.008 \\
\hline 11 & 18 & very high & Liechtenstein & 1.0093 \\
\hline 12 & 19 & very high & Israel & 1.0098 \\
\hline 13 & 26 & very high & Italy & 1.0111 \\
\hline 14 & 27 & very high & Spain & 1.0123 \\
\hline 15 & 8 & very high & Canada & 1.0153 \\
\hline 16 & 12 & very high & Sweden & 1.0154 \\
\hline 17 & 7 & very high & New Zealand & 1.0173 \\
\hline 18 & 20 & very high & France & 1.0188 \\
\hline 19 & 16 & very high & Korea (Republic of) & 1.0192 \\
\hline 20 & 4 & very high & Netherlands & 1.0217 \\
\hline 21 & 23 & very high & Luxembourg & 1.0243 \\
\hline 22 & 11 & very high & Ireland & 1.0246 \\
\hline 23 & 14 & very high & United Kingdom & 1.0259 \\
\hline 24 & 21 & very high & Austria & 1.0269 \\
\hline 25 & 37 & very high & Andorra & 1.0289 \\
\hline 26 & 29 & very high & Greece & 1.0299 \\
\hline 27 & 24 & very high & Finland & 1.0313 \\
\hline 28 & 22 & very high & Belgium & 1.0332 \\
\hline 29 & 10 & very high & Denmark & 1.0401 \\
\hline 30 & 32 & very high & Cyprus & 1.0406 \\
\hline 31 & 42 & very high & Portugal & 1.0406 \\
\hline 32 & 25 & very high & Slovenia & 1.0409 \\
\hline 33 & 35 & very high & Lithuania & 1.0421 \\
\hline 34 & 41 & very high & Chile & 1.044 \\
\hline 35 & 65 & high & Lebanon & 1.0447 \\
\hline 36 & 68 & high & Costa Rica & 1.0457 \\
\hline 37 & 30 & very high & Brunei Darussalam & 1.0461 \\
\hline 38 & 28 & very high & Czech Republic & 1.0468 \\
\hline 39 & 39 & very high & Malta & 1.048 \\
\hline 40 & 45 & very high & Cuba & 1.0545 \\
\hline 41 & 60 & high & Palau & 1.0625 \\
\hline 42 & 80 & high & Georgia & 1.0692 \\
\hline 43 & 103 & medium & Maldives & 1.0727 \\
\hline 44 & 33 & very high & Estonia & 1.0737 \\
\hline 45 & 46 & very high & Kuwait & 1.0759 \\
\hline 46 & 94 & high & Dominica & 1.0761 \\
\hline 47 & 66 & high & Panama & 1.0777 \\
\hline 48 & 50 & high & Uruguay & 1.0779 \\
\hline 49 & 40 & very high & The United Arab Emirates & 1.078 \\
\hline
\end{tabular}


Table 5. Data and optimization results for the countries in a group of high human development according to the proposed "Output-Oriented Super Efficiency VRS DEA Model without Inputs"

\begin{tabular}{|c|c|c|c|c|}
\hline New Ranking & HDI Ranking & HDI Group & Countries & Efficiency Scores \\
\hline 50 & 71 & high & Mexico & 1.0784 \\
\hline 51 & 36 & very high & Poland & 1.080 \\
\hline 52 & 95 & high & Albania & 1.080 \\
\hline 53 & 47 & very high & Croatia & 1.0802 \\
\hline 54 & 49 & very high & Argentina & 1.0875 \\
\hline 55 & 44 & very high & Bahrain & 1.0898 \\
\hline 56 & 56 & high & Oman & 1.0902 \\
\hline 57 & 99 & high & Ecuador & 1.093 \\
\hline 58 & 34 & very high & Saudi Arabia & 1.0944 \\
\hline 59 & 86 & high & Bosnia and Herzegovina & 1.0944 \\
\hline 60 & 38 & very high & Slovakia & 1.0956 \\
\hline 61 & 90 & high & Tunisia & 1.0993 \\
\hline 62 & 61 & high & Antigua and Barbuda & 1.1004 \\
\hline 63 & 122 & medium & Viet Nam & 1.1005 \\
\hline 64 & 55 & high & Libya & 1.102 \\
\hline 65 & 57 & high & Russian Federation & 1.1036 \\
\hline 66 & 59 & high & Barbados & 1.1036 \\
\hline 67 & 51 & high & Bahamas & 1.1043 \\
\hline 68 & 43 & very high & Hungary & 1.1084 \\
\hline 69 & 69 & high & Turkey & 1.1085 \\
\hline 70 & 91 & high & China & 1.1095 \\
\hline 71 & 85 & high & $\begin{array}{l}\text { The former Yugoslav Republic of } \\
\text { Macedonia }\end{array}$ & 1.1115 \\
\hline 72 & 52 & high & Montenegro & 1.112 \\
\hline 73 & 123 & medium & Cape Verde & 1.113 \\
\hline 74 & 62 & high & Malaysia & 1.1141 \\
\hline 75 & 87 & high & Armenia & 1.1149 \\
\hline 76 & 132 & medium & Nicaragua & 1.1168 \\
\hline 77 & 82 & high & Peru & 1.117 \\
\hline 78 & 97 & high & Saint Lucia & 1.1173 \\
\hline 79 & 67 & high & Venezuela (Bolivarian Republic of) & 1.1181 \\
\hline 80 & 74 & high & Sri Lanka & 1.1184 \\
\hline 81 & 53 & high & Belarus & 1.1198 \\
\hline 82 & 119 & medium & The Syrian Arab Republic & 1.1211 \\
\hline 83 & 75 & high & Iran (The Islamic Republic of) & 1.1231 \\
\hline 84 & 89 & high & Thailand & 1.1234 \\
\hline 85 & 48 & very high & Latvia & 1.1239 \\
\hline 86 & 79 & high & Brazil & 1.1247 \\
\hline 87 & 54 & high & Romania & 1.1259 \\
\hline 88 & 63 & high & Mauritius & 1.128 \\
\hline 89 & 78 & high & Serbia & 1.1284 \\
\hline 90 & 98 & high & Colombia & 1.1289 \\
\hline 91 & 84 & high & Belize & 1.1307 \\
\hline 92 & 58 & high & Bulgaria & 1.1312 \\
\hline 93 & 77 & high & Jordan & 1.1317 \\
\hline 94 & 129 & medium & Honduras & 1.1323 \\
\hline 95 & 73 & high & Saint Kitts and Nevis & 1.1361 \\
\hline 96 & 96 & high & Jamaica & 1.1368 \\
\hline 97 & 102 & high & Dominican Republic & 1.1387 \\
\hline 98 & 106 & medium & Samoa & 1.1394 \\
\hline 99 & 81 & high & Grenada & 1.1398 \\
\hline 100 & 107 & medium & Palestine. State of & 1.1418 \\
\hline 101 & 72 & high & Seychelles & 1.142 \\
\hline 102 & 83 & high & Ukraine & 1.1442 \\
\hline
\end{tabular}


Table 6. Data and optimization results for the countries in a group of medium human development according to the proposed "Output-Oriented Super Efficiency VRS DEA Model without Inputs"

\begin{tabular}{|c|c|c|c|c|}
\hline New Ranking & HDI Ranking & HDI Group & Countries & Efficiency Scores \\
\hline 103 & 101 & high & Tonga & 1.1451 \\
\hline 104 & 115 & medium & El Salvador & 1.1513 \\
\hline 105 & 92 & high & Saint Vincent and the Grenadines & 1.1529 \\
\hline 106 & 76 & high & Azerbaijan & 1.1535 \\
\hline 107 & 111 & medium & Paraguay & 1.1567 \\
\hline 108 & 125 & medium & Guatemala & 1.1592 \\
\hline 109 & 137 & medium & Cambodia & 1.1622 \\
\hline 110 & 131 & medium & Vanuatu & 1.1669 \\
\hline 111 & 93 & high & Algeria & 1.1734 \\
\hline 112 & 110 & medium & Egypt & 1.1746 \\
\hline 113 & 100 & high & Suriname & 1.1769 \\
\hline 114 & 130 & medium & Morocco & 1.1782 \\
\hline 115 & 108 & medium & Indonesia & 1.18 \\
\hline 116 & 64 & high & Trinidad and Tobago & 1.1818 \\
\hline 117 & 142 & medium & Bangladesh & 1.1829 \\
\hline 118 & 88 & high & Fiji & 1.186 \\
\hline 119 & 120 & medium & Iraq & 1.204 \\
\hline 120 & 114 & medium & Moldova (Republic of) & 1.2092 \\
\hline 121 & 124 & medium & $\begin{array}{l}\text { Micronesia (The Federated States } \\
\text { of) }\end{array}$ & 1.2114 \\
\hline 122 & 133 & medium & Kiribati & 1.213 \\
\hline 123 & 117 & medium & Philippines & 1.2165 \\
\hline 124 & 116 & medium & Uzbekistan & 1.2172 \\
\hline 125 & 145 & low & Nepal & 1.2218 \\
\hline 126 & 139 & medium & $\begin{array}{l}\text { Lao People's Democratic } \\
\text { Republic }\end{array}$ & 1.2236 \\
\hline 127 & 136 & medium & Bhutan & 1.2238 \\
\hline 128 & 104 & medium & Mongolia & 1.2273 \\
\hline 129 & 134 & medium & Tajikistan & 1.2346 \\
\hline 130 & 158 & low & Solomon Islands & 1.235 \\
\hline 131 & 70 & high & Kazakhstan & 1.2362 \\
\hline 132 & 126 & medium & Kyrgyzstan & 1.237 \\
\hline 133 & 128 & medium & Timor-Leste & 1.2375 \\
\hline 134 & 113 & medium & Bolivia (Plurinational State of) & 1.2389 \\
\hline 135 & 146 & low & Pakistan & 1.2555 \\
\hline 136 & 135 & medium & India & 1.2585 \\
\hline 137 & 143 & medium & Sao Tome and Principe & 1.2599 \\
\hline 138 & 121 & medium & Guyana & 1.2607 \\
\hline 139 & 105 & medium & Turkmenistan & 1.2643 \\
\hline 140 & 150 & low & Myanmar & 1.2824 \\
\hline 141 & 155 & low & Madagascar & 1.2913 \\
\hline 142 & 127 & medium & Namibia & 1.2962 \\
\hline 143 & 151 & low & Rwanda & 1.2979 \\
\hline 144 & 109 & medium & Botswana & 1.2981 \\
\hline
\end{tabular}


Table 7. Data and optimization results for the countries in a group of lower human development according to the proposed "Output-Oriented Super Efficiency VRS DEA Model without Inputs"

\begin{tabular}{|c|c|c|c|c|}
\hline New Ranking & HDI Ranking & HDI Group & Countries & Efficiency Scores \\
\hline 145 & 118 & medium & South Africa & 1.2994 \\
\hline 146 & 173 & low & Ethiopia & 1.3134 \\
\hline 147 & 112 & medium & Gabon & 1.3135 \\
\hline 148 & 163 & low & Senegal & 1.3172 \\
\hline 149 & 154 & low & Yemen & 1.3243 \\
\hline 150 & 168 & low & Haiti & 1.3245 \\
\hline 151 & 182 & low & Eritrea & 1.3298 \\
\hline 152 & 157 & low & Papua New Guinea & 1.339 \\
\hline 153 & 166 & low & Sudan & 1.3469 \\
\hline 154 & 170 & low & Djibouti & 1.3524 \\
\hline 155 & 147 & low & Kenya & 1.3543 \\
\hline 156 & 161 & low & Mauritania & 1.3579 \\
\hline 157 & 160 & low & $\begin{array}{l}\text { Tanzania (The United Republic } \\
\text { of) }\end{array}$ & 1.3584 \\
\hline 158 & 159 & low & Comoros & 1.3646 \\
\hline 159 & 138 & medium & Ghana & 1.3656 \\
\hline 160 & 169 & low & Afghanistan & 1.3714 \\
\hline 161 & 175 & low & Liberia & 1.3802 \\
\hline 162 & 156 & low & Zimbabwe & 1.396 \\
\hline 163 & 165 & low & Benin & 1.408 \\
\hline 164 & 164 & low & Uganda & 1.4116 \\
\hline 165 & 140 & medium & Congo & 1.4198 \\
\hline 166 & 172 & low & Gambia & 1.421 \\
\hline 167 & 141 & medium & Zambia & 1.4226 \\
\hline 168 & 187 & low & Niger & 1.4309 \\
\hline 169 & 167 & low & Togo & 1.4675 \\
\hline 170 & 181 & low & Burkina Faso & 1.4834 \\
\hline 171 & 179 & low & Guinea & 1.4895 \\
\hline 172 & 174 & low & Malawi & 1.5069 \\
\hline 173 & 152 & low & Cameroon & 1.5159 \\
\hline 174 & 176 & low & Mali & 1.5188 \\
\hline 175 & 177 & low & Guinea-Bissau & 1.5395 \\
\hline 176 & 180 & low & Burundi & 1.5435 \\
\hline 177 & 144 & medium & Equatorial Guinea & 1.5751 \\
\hline 178 & 153 & low & Nigeria & 1.5918 \\
\hline 179 & 149 & low & Angola & 1.5972 \\
\hline 180 & 184 & low & Chad & 1.633 \\
\hline 181 & 171 & low & Côte d'Ivoire & 1.6478 \\
\hline 182 & 178 & low & Mozambique & 1.661 \\
\hline 183 & 185 & low & The Central African Republic & 1.6656 \\
\hline 184 & 186 & low & $\begin{array}{l}\text { Congo (The Democratic } \\
\text { Republic of the) }\end{array}$ & 1.6687 \\
\hline 185 & 162 & low & Lesotho & 1.6747 \\
\hline 186 & 148 & low & Swaziland & 1.6876 \\
\hline 187 & 183 & low & Sierra Leone & 1.8345 \\
\hline
\end{tabular}




\section{CONCLUSIONS}

Although there are different opinions related to dimensions and indicators regarding the measure of human development, the main opinion is related to its calculation method. If the calculation method is correctly determined, then the dimensions and indicators by appropriate analytical framework and methodology can be constructed. So, the HDI being a popular measure of human well-being has become a measure of human development. HDI was being computed by the average of the four HDI indicators until 2010. Then countries were ranked according to this overall index. In the 2010 and 2011 HDRs, UNDP changed its method of computing the HDI from simple average to geometric average. However, this new method is still being faced some criticisms. The first group of critiques relates to the fact that three component indices of HDI are taken into consideration as equal weights. The second group of critiques relates to normalization technique of variables used in the calculation of the index. Because as a result of normalization, the main structure of the data changes. If so, the relative position of the countries in the HDI ranking can be attributed to two main reasons: One is structural and is related to the data themselves, the other is linked with the particular weighting scheme (equal weights) used in the HDI. In this study, considering these shortcomings, the measurement of human development has been again revisited in the light of DEA. DEA analysis is an appropriate tool for the measurement and analysis of issues related to human development by evaluating the efficiency in generating quality of life from wealth or economic, social and environmental resources. All of the variables LE, MS, ES, GNIpc used in HDI account were taken as output variables to measure the performance of the countries by the DEA analysis in this study. The Radial based DEA model without inputs developed by Lovell and Pastor (1999) was used for a case which an efficiency measurement through output variables in the absence of input variables was performed. In order to rank the performance of efficient DMUs (herein, the countries) according to the optimal solution of the output-oriented radial DEA model without inputs, the formulation of superefficiency model developed by Andersen and Petersen (1993) was applied to the Radial based DEA model without inputs, which it is considered as the output of all of the relevant variables, and developed by Lovell and Pastor (1999). Hence, the ranking of the countries was provided. As a result of the findings, a new scaling named the outputoriented super-efficiency DEA model without inputs put forward by this study as an alternative to the traditional HDI scale to measure human development was proposed. The problems relating to the data structure and the particular weighting scheme (equal weights), which are encountered in HDI calculations, were tried to be eliminated by the proposed method.

\section{References}

Andersen, P., \& Petersen, N.C. (1993). A procedure for ranking efficient units in data envelopment analysis. Management science, 39 (10), 1261-1264.

Baliamoune-Lutz, M., \& McGillivray, M. (2006). Fuzzy well-being achievement in Pacific Asia. Journal of the Asia Pacific Economy, 11 (2), 168-177.

Banker, R. D., Charnes, A., \& Cooper, W. 


\title{
ПРОЦЕНА ИНДЕКСА ЉУДСКОГ РАЗВОЈА УПОРЕБЕЊЕМ МОДЕЛА СУПЕР ЕФИКАСНОСТИ ОРИЈЕНТИСАНЕ НА ОДЗИВЕ НАСУПРОТ ДЕА МОДЕЛА БЕЗ УЛАЗНИХ ПРОМЕЊИВИХ
}

\author{
Miraç Eren, Murat Eren, Selim Başar
}

Извод

Индекс људског развоја (ХДИ) који је популарна мера добробити човечанства, постао је мера развоја људске заједнице. Ипак, ХДИ добија и значајне критике које се односе на структуру података и посебно одређивања тежинских коефицијената. У овој студији, извршено је мерење људског развоја и кроз методологију анализе садржајности података (ДЕА), у циљу елиминације недостарака ХДИ методе. Све промењиве које се узимају при ХДИ анализи су узете као излазне промењиве како би се упоредиле релативне перформансе међу државама. У недостатку улазних промењивих, и у случају где су само излазне варијабле на располагању, извршено је реорганизовање формулисањем модела супер - ефикасности који су развили Andersen и Petersen (1993). Добијена формулација је примењена на ДЕА модел радијалне основе, без улазних величина, који се сматра излазом свих релевантних варијабли , према истраживању Lovell и Pastor-a (1999).

Кључне речи: Индекс људског развоја, анализа обухвата података; ефикасност

W. (1984). Some models for estimating technical and scale inefficiencies in data envelopment analysis. Management Science, 30 (9), 1078-1092.

Bhanojirao, V. (1991). Human development report 1990: review and assessment. World Development, 19 (10), 1451-1460.

Charnes, A., Cooper, W. W., \& Rhodes, E. (1978). Measuring the efficiency of decisionmaking units. European journal of operational research, 2 (6), 429-444.

Coelli, T., \& Perelman, S. (2000). Technical efficiency of European railways: a distance function approach. Applied Economics, 32 (15), 1967-1976.

Cooper, W.W., Seiford, L.M., \& Tone, K. (2007). Data envelopment analysis: a comprehensive text with models, applications, references and DEA-solver software: Springer Science \& Business Media.

Cooper, W.W., Seiford, L.M., \& Zhu, J. (2011). Data envelopment analysis: History, models, and interpretations Handbook on data envelopment analysis (pp. 1-39): Springer.

De Witte, K., Rogge, N., Cherchye, L., \& Van Puyenbroeck, T. (2013). Economies of scope in research and teaching: A nonparametric investigation. Omega, 41 (2), 305314.

Despotis, D. (2005). Measuring human development via data envelopment analysis: the case of Asia and the Pacific. Omega, 33 (5), 385-390.

Dias, R.A., Mattos, C.R., \& Balestieri, J.A. (2006). The limits of human development and the use of energy and natural resources. Energy Policy, 34 (9), 1026-1031.

PO (DPT), State Planning Organization (2007). Ninth Five-Year Development Plan. Labor Market Specialization Commission Report (In Turkish).

Ebadi, S. (2012). Using a Super Efficiency Model for Ranking units in DEA. Applied Mathematical Sciences, 6 (41), 2043-2048. 
Engineer, M., King, I., \& Roy, N. (2008). The human development index as a criterion for optimal planning. Indian Growth and Development Review, 1 (2), 172-192.

Färe, R., \& Karagiannis, G. (2014). Benefitof-the-doubt aggregation and the diet problem. Omega, 47, 33-35.

Harttgen, K., \& Klasen, S. (2012). A household-based human development index. World Development, 40 (5), 878-899.

Hicks, D.A. (1997). The inequality-adjusted human development index: a constructive proposal. World Development, 25 (8), 12831298.

Kelley, A.C. (1991). The Human Development Index:" Handle with Care". Population and Development Review, 17 (2), 315-324.

Lovell, C.K., \& Pastor, J.T. (1999). Radial DEA models without inputs or without outputs. European Journal of operational research, 118 (1), 46-51.

Mahlberg, B., \& Obersteiner, M. (2001). Remeasuring the HDI by data envelopement analysis. Available at SSRN 1999372.

Mariano, E.B., Sobreiro, V.A., \& do Nascimento Rebelatto, D.A. (2015). Human development and data envelopment analysis: A structured literature review. Omega, 54, 33-49.

Moran, D.D., Wackernagel, M., Kitzes, J.A., Goldfinger, S.H., \& Boutaud, A. (2008). Measuring sustainable development-Nation by nation. Ecological Economics, 64 (3), 470474.

Morse, S. (2003). Greening the United Nations' human development index? Sustainable Development, 11 (4), 183-198.

Neumayer, E. (2001). The human development index and sustainability-a constructive proposal. Ecological Economics, 39 (1), 101-114.

Noorbakhsh, F. (1998). A modified human development index. World Development, 26 (3), 517-528.

Ogwang, T. (1994). The choice of principle variables for computing the Human Development Index. World Development, 22 (12), 2011-2014.

Poveda, A.C. (2011). Economic development and growth in Colombia: An empirical analysis with super-efficiency DEA and panel data models. Socio-Economic Planning Sciences, 45 (4), 154-164.

Prados de la Escosura, L. (2015). World human development: 1870-2007. Review of Income and Wealth, 61 (2), 220-247.

Ranis, G., Stewart, F., \& Samman, E. (2005). Human development: Beyond the HDI. Yale University Economic Growth Center Discussion Paper (916).

Ravallion, M. (1997). Good and bad growth: the human development reports. World Development, 25 (5), 631-638.

Ravallion, M. (2012). Troubling tradeoffs in the human development index. Journal of Development Economics, 99 (2), 201-209.

Safari, H., \& Ebrahimi, E. (2014). Using Modified Similarity Multiple criteria Decision Making technique to rank countries in terms of Human Development Index.

Sagar, A.D., \& Najam, A. (1998). The human development index: a critical review. Ecological Economics, 25 (3), 249-264.

Sanusi, Y.A. (2008). Application of human development index to measurement of deprivations among urban households in Minna, Nigeria. Habitat International, 32 (3), 384-398.

Srinivasan, T.N. (1994). Human development: a new paradigm or reinvention of the wheel? The American Economic Review, 84, 238-243.

UNDP. (1995). Human Development Report. New York: UNDP.

Wolff, H., Chong, H., \& Auffhammer, M. (2011). Classification, Detection and Consequences of Data Error: Evidence from the Human Development Index*. The Economic Journal, 121 (553), 843-870. 